\title{
Major Foreign Language Pedagogic Schools in Western Countries and Their Illumination on English Teaching in China
}

\author{
Ming Cai \\ Xinyang Agriculture and Forestry University \\ School of Foreign Languages, Xinyang Agriculture and Forestry University, Xinyang, China \\ 329495213@qq.com
}

Keywords: Foreign language pedagogic schools, China’s English teaching, Illumination

\begin{abstract}
This thesis intends to make a detailed comparison among the six influential foreign language pedagogic schools, with the aim to acquire some illumination for English teaching and find the most suitable way for English teaching in China. After the analyses, the thesis concludes that a suitable way for English teaching in China is to combine different pedagogic methods and approaches together and take advantage of the merits of each method.
\end{abstract}

\section{Introduction}

For hundreds of years, many linguists and scholars have devoted themselves to the study of foreign language pedagogies. Accordingly, in different periods of time, different foreign language pedagogic schools have emerged in different regions and countries, among which some schools are most representative, for example, the Grammar-Translation Method, the Direct Method, the Audio-Lingual Method, the Audio-Visual Approach, the Cognitive Approach, the Communicative Approach and so on. These foreign language pedagogies themselves have both advantages and disadvantages.

As the process of internationalization has paced up, more and more Chinese begin to use English, an international language, as a tool for international communication. As a result, more attention is paid on English teaching in China. Chinese teachers and scholars have researched and tried different teaching methods in English teaching.

This thesis intends to make a detailed comparison among six influential foreign language pedagogic schools, with the aim to acquire some illumination for English teaching and to find the most suitable way for English teaching in China.

As to the layout of this thesis, it consists of four chapters, together with introduction and conclusion. Chapter 1 is introduction, which states the background and aims of the thesis, and outlines the general structure of the thesis. Chapter 2 analyzes the six major foreign language pedagogic schools in Western Countries, in which both the advantages and disadvantages of the pedagogic schools will be elaborated. In Chapter 3, combined with the different current situations and features of different teaching periods, the thesis analyzes the problems existing in different teaching periods and aims to find some illumination for different teaching periods. Chapter 4 is conclusion. 


\section{Analysis on the Major Foreign Language Pedagogic Schools in Western Countries}

This chapter is an overview on the major foreign language pedagogic schools in western countries, in which the definitions, advantages and disadvantages of the six major pedagogic schools will be discussed.

\subsection{The Grammar-Translation Method}

The Grammar Translation Method has dominated foreign language teaching for many years, and it is still widely used, though it is a method for which there is no theory.

\subsubsection{The Definition of the Grammar-Translation Method}

The Grammar-Translation Method makes use of translation and grammar study as the main teaching and learning activities. It was the traditional way Latin and Greek were taught in Europe. In the $19^{\text {th }}$ Century it began to be used to teach "modern" languages such as French, German, and English, and it is still used in some countries today. A typical lesson consists of the presentation of a grammatical rule, a study of lists of vocabulary, and a translation exercise. It emphasizes reading rather than the ability to communicate in a language. (Richards, Jack C and Richard Schmidt, 2005, p.297) ${ }^{[8]}$

\subsubsection{Analysis on the Grammar-Translation Method}

This method focuses on grammar and translation, which helps students lay a solid grammatical foundation to express accurately and improve translation skills. It can also make full use of the native language and save the teacher's energy and time. Therefore, it doesn't require the modern equipment and facilities and the teacher is the center of the classroom activity.

However, the disadvantages of this method are obvious. It neglects the cultivation of students' language skills, as a result, the learners only learn the rules instead of the language, leading them to find themselves in great difficulty to open mouth to communicate in the foreign language. It overemphasizes the function of translation and ignores other skills of training. In this way it is likely to reduce students' interest in learning a foreign language and lead to a dull atmosphere of teaching.

\subsection{The Direct Method}

The Direct Method was the product of the foreign language teaching reform campaign in western Europe in the $19^{\text {th }}$ Century and was greatly influenced by the Stimulus-Response theory of behaviorism. Moreover, it has a strong influence on foreign language teaching of China in the first half of the $20^{\text {th }}$ Century.

\subsubsection{The Definition of the Direct Method}

"The Direct Method was developed in the late $19^{\text {th }}$ Century as a reaction against the Grammar Translation Method and was the first oral-based method to become widely adopted." (Richards, Jack C and Richard Schmidt, 2005, p.205 ${ }^{[8]}$ It considers language is a skill instead of a kind of science, believing that verbal language comes first before written language. Moreover, it advocates language is a habit based on repeated exercises and imitation, adhering to using a foreign language to teach foreign language. 


\subsubsection{Analysis on the Direct Method}

The Direct Method carries out an effective system of oral practice and teaches vivid language, attaching importance to phonetics. It offers innovations at the level of teaching procedures, such as using gestures, actions, expressions, pictures and other direct ways. The learners are always put in an environment of the foreign language they're learning and think and speak in a way as the foreign language speakers.

On the other, this method doesn't take the practical realities of the classroom into account and overemphasizes the role of the teacher. In this circumstance it requires the teacher to be quite fluent of the foreign language. And it stresses too much on experience and on negative effects of mother tongue in foreign language teaching, ignoring its positive effects. Although applying this method could train students to have a good command of oral English, they have difficulty in reading lengthy and complex sentences.

\subsection{The Audio-Lingual Method}

The Audio-Lingual Method derives from American Army Specialized Training Program and bases itself both on behaviorism and structuralism. Apparently it is a linguistic or structure-based approach to foreign language teaching.

\subsubsection{The Definition of the Audio-Lingual Method}

The Audio-Lingual Method is a method of foreign or second language teaching which emphasizes the teaching of speaking and listening before reading and writing, uses dialogues and drills, discourages use of the mother tongue in the classroom and often makes use of contrastive analysis. It was prominent in the 1950s and 1960s, especially in the United States, and it has been widely used in many other parts of the world. (Richards, Jack C and Richard Schmidt, 2005, p.50) ${ }^{[8]}$

\subsubsection{Analysis on the Audio-Lingual Method}

This method reckons that language has its own mode and it is a process of forming habit to learn a language. It concentrates on speaking and emphasizes sentence structure. Language learning is considered as the active verbal interaction between the teacher and the learners. By using modern devices flexibly in foreign language teaching, it improves the ability of listening and speaking of the learners.

However, this method ignores the cognitive and thinking ability of human brains. The sentence practice is always quite mechanical, which is not beneficial for the learners to cultivate communicative skills. It overemphasizes speaking while ignores grammar and the ability of reading and writing.

\subsection{The Audio-Visual Method}

The Audio-Visual Method originated from France in the 1950s and held a view that the training of listening and speaking should be based on some situations. So it is also called The Situational Approach.

\subsubsection{The Definition of the Audio-Visual Method}

"The Audio-Visual Method, as the term suggests, is a teaching approach in which the feelings of visual sense and sense of hearing are combined. It originated from the Direct Method and the 
Audio-Lingual Method.” (Mueller, T., 1955, p.293) ${ }^{[4]}$ And it emphasizes the combination of visual sense (pictures and videos) and sense of hearing (recording) in a certain situation.

\subsubsection{Analysis on the Audio-Visual Method}

Just like the Audio-Lingual Method, this method advocates teaching speaking and listening before reading and writing, in which the mother tongue is not used in the classroom. And modern devices are adopted freely. Dialogues in everyday life situations are the center of teaching, which tallies more with the needs of the students' speech communication than the previous Grammar-Translation, the Direct Method and the Audio-Lingual Method. Moreover, from the very beginning students are required to listen to standard and idiomatic recordings of the foreign language and practice speaking the language frequently. This helps the students cultivate the ability for correct pronunciation, intonation, rhythm, wording and phrasing and shape good language habits as well.

The weak points of this method are: it places too much stress on mastering the language materials through imitation of integrated structures and repeated reappearance of the materials while neglects appropriate analysis, explanation and practice of single structure and unit in the language, which is detrimental to the students' understanding and applying of the foreign language; it attaches too much importance to the role of visual sense, but overlooks the positive supplementary part played by the mother tongue in explaining abstract words and grammatical structures.

\subsection{The Cognitive Approach}

The Cognitive Approach was proposed by American psychologists in the 1960s and was based on cognitive psychology and the theory of Transformational-generative grammar.

\subsubsection{The Definition of the Cognitive Approach}

"The Cognitive Approach is an approach to foreign language teaching which is based on the belief that language learning is a process which involves active method processes and not simply the forming of habits. It lays emphasis on the conscious acquisition of language as a meaningful system.” (Hawatt, A. P. R., 1984, p.253)

\subsubsection{Analysis on the Cognitive Approach}

In Cognitive Approach, the learner is seen as an active participant in the learning process, using various mental strategies in order to sort out the system of the language to be taught. The Cognitive Approach involves more active use of the students' mental power, which is especially suitable for adult language learners. The students are the center of foreign language teaching. Moreover, this approach gives equal emphasis to listening, speaking, reading and writing. And it agrees to utilize mother tongue and translation method to help learn the foreign language. In addition, it applies various teaching devices to make the teaching situational and communicative.

One weak point of this approach is there are not yet complete and systematic practical activities and procedures for classroom use. And the rationale behind the method is still at its developmental stage. The method as a system is still not very complete and needs further research and development. 


\subsection{The Communicative Approach}

It is a learner-centered and experience-based view of second language teaching. A person who acquires communicative competence acquires both knowledge and ability for language use. This approach pays attention to functional and structural aspects of language.

\subsubsection{The Definition of the Communicative Approach}

Communicative Approach is an approach to foreign or second language teaching which emphasizes that the goal of language learning is communicative competence and which seeks to make meaningful communication and language use a focus of all classroom activities. The communicative approach was developed particularly by British applied linguists in the 1980s as a reaction away from grammar-based approaches such as situational language teaching and the audio-lingual method. (Richards, Jack C and Richard Schmidt, 2005, p.50) ${ }^{[6]}$

\subsubsection{Analysis on the Communicative Approach}

The Communicative Approach is easy to be applied to the teaching of any skill, at any level owing to the wide variety of classroom activities and exercise types. It is a more humanistic approach to teaching, devoting to the enhancement of learners' communicative competence in learners' practical needs. Therefore, this approach makes the teaching objectives clear and can help learners to apply the foreign language in concrete social language communicative abilities. Besides, it doesn't exclude mother tongue and translation method to help learners learn the foreign language.

Despite those advantages, there are still some problems requiring further research: how to balance the relationship between the function of language and the structure of language; how to judge the authenticity of teaching materials and situations; how close it is practically to tailor a syllabus to learners' needs. And it is not easy to develop language competence while at the same time develop communicative competence.

\section{The Illumination on English Teaching of China}

On account of the different conditions and features of different teaching periods, it is better for us to discuss the illumination of foreign language pedagogic schools from three periods - the period of primary school, the period of junior and senior middle school and the period of university.

\subsection{The Period of Primary School}

Students in this period are quite young, lively and imitative. So some suitable teaching methods such as the Direct Method and the Audio-Lingual Method should be adopted. Moreover, more suitable methods can be applied according to the conditions of students and teachers.

\subsubsection{Current Situation and the Problems of Primary School English Teaching}

In China, it's an essential part of the reform of basic courses to set up English course in primary school in the early $21^{\text {st }}$ Century, and now English education often starts at Grade 3 in primary school. In this period, the main tasks of English teachers are to help students simply express the things they encounter in daily life in English and to have a simple communication in English with the teachers.

There exist many problems in English teaching of China's primary school. First, the teaching 
goal is not so clear. In an exam-oriented environment, with English examination not a necessary one related to graduation and going to middle school, English course is ignored and many schools only pay attention to the teaching form instead of the effects. Second, teachers' teaching level is not so qualified for the necessary teaching level. Third, in the process of teaching, too much attention is paid on vocabulary and grammar rules. On the contrary, to cultivate students' language competence is ignored. Fourthly, scientific teaching methods are not adopted. The teachers still follow the simple teaching mode of “ explanation-reading-exercise”. This teaching method is quite monotonous, dull and ineffective.

\subsubsection{The Illumination on the Primary School English Teaching}

First, in this period, the influence their mother tongue brings to the students is not so obvious, and the students have a quite strong imitating ability. So emphasis should be given on listening and speaking skills, oral expression and the accuracy of pronunciations. Besides, among the pedagogic schools above, the Direct Method and the Audio-Lingual Method are most suitable and effective for younger students. So we should adopt the Direct Method, including the Audio-Lingual Method and Audio-Visual Method which developed from the Direct Method, as the main teaching method. Second, after the students have learned some English sentences, the Communicative Approach can be utilized properly to improve students' English by dialogues and role-play. Third, primary students are apt to accept interesting things, so one simple teaching method is not appropriate. Multiple teaching methods and approaches including playing games, singing English songs and a combination of the teaching methods above can be applied, which will make teaching more flexible and interesting.

\subsection{The Period of Junior and Senior Middle School}

In this period, the students' cognition and understanding ability have been improved. And in recent years, the Communicative Approach has been advocated in the teaching of this period. However, more effective and various methods should be adopted.

\subsubsection{Current Situation and the Problems of Middle School English Teaching}

This period belongs to the basic period of English learning. The new middle school English Curriculum Standard not only attaches importance to the teaching of English as knowledge, but also sets raising students' ability to use English in their daily life as a major goal for teaching English. And in recent years, although the Communicative Approach has been advocated and adopted in China's English teaching, its effect is not so ideal. Many students still couldn't speak English very well.

The problems of this period are: First, the teacher has been the center of classroom activities and students' role is passive in the classroom. In the classroom teaching, the teacher is extremely authoritative in making decisions about what going on, such as what to learn, how to learn and at what time to learn, while students are expected to listen to teachers without interruption, sitting quietly and listening attentively. (Zhang Yurang, 2008, p.7) ${ }^{[8]}$ Second, in the exam-oriented environment of education, teachers teach whatever comes up in the examinations; their responsibility is to enable the students to pass various foreign language tests and examinations. English is just regarded as an academic subject and the purpose of teaching it is not to prepare for the practical use of the language, but to create the linguistic competence and language knowledge. Third, many teachers have misunderstood the Communicative Approach and overestimated the effects of it and think this approach is universal while the positive effects other teaching methods 
and approaches bring to English teaching are ignored.

\subsubsection{The Illumination on the Middle School English Teaching}

First, there is no doubt that the Communicative Approach should be used. For a long time, we have stressed too much on the teaching of language itself, but neglected communicative competence. It is beneficial to utilize the Communicative Approach in English teaching. However, we should realize that it is not the only suitable and effective approach for other methods and approaches also have advantages. Second, students in this period should have a relatively complete command of grammar and vocabulary with the grammar explanation not isolated; they should master both the ability of reading and writing and the ability of listening and speaking. So in this period, various teaching methods should be applied. The Grammar-Translation Method, the Cognitive Approach and the Communicative Approach should equally be put in the first place and the Direct Method, the Audio-Lingual Method and the Audio-Visual Method should also be used and put in the second place.

\subsection{The Period of University Times}

In this period, the students are to have a good basic command of English; however, the condition is not so satisfactory. There exist many problems in this period and every effective and suitable method should be used in English teaching in this period.

\subsubsection{Current Situation and the Problems of University English Teaching}

This period includes the phase of undergraduate and that of postgraduate, which belongs to the senior stage of English learning. The College English Curriculum Requirements published by the Ministry of Education in January, 2004 determines the nature of college English teaching course as a component of higher education and a compulsory subject for college students. The course contents language knowledge, skills to apply the language, learning strategies and cross-culture communication competence. The general teaching goal is to cultivate students' ability to use language comprehensively. However, the condition of college students' English learning is not so satisfactory. By the time they enter college, Chinese students usually have completed at least six years of English classes, yet most are unable to carry on simple conversations with native speakers or write sentences free of basic grammatical errors. Even after graduation, the undergraduates still have difficulties in communicating in English in daily life and reading English books; and the postgraduates who can write their theses in English are less than $10 \%$ of them.

A lot of problems exist in this period. First, the exam-oriented education made the teaching not for learning knowledge but for passing examinations. These years, whether a college student could graduate is closely related to whether he or she has passed CET-4 or CET-6. The English teaching tends to do a lot of exercises for examinations, ignoring to cultivate students' communicative competence in English. Second, according to a survey, over 70\% of the teachers acknowledged that they still applied the Grammar-Translation Method in teaching English. They explained that though they knew the Communicative Approach was popular at present, they still found the Grammar-Translation Method be more "practical” due to various reasons such as limited time, the number of students and the pressure from examinations. ${ }^{[2]}$

\subsubsection{The Illumination on the University English Teaching}

First of all, in this period, students have mastered the basic language knowledge and have a 
relatively comprehensive ability of listening, speaking, reading and writing with self-learning ability. It will be advantageous for teaching if the Communicative Approach is adopted in this period, for it could effectively consolidate the knowledge students have learned and improve their proficiency in using the language. On the other hand, we should not forget to combine the Communicative Approach with other teaching methods and approaches. The Grammar-Translation Method is especially effective to analyze some complex sentences; the Audio-Lingual Method emphasizes on sentence teaching and oral speaking; the Cognitive Approach could make the best of students' cognitive potential. All in all, every teaching method has its advantages and teachers should make the best of it.

\section{Conclusion}

From the analysis in Chapter 2, we can see that different pedagogic schools have their own unique advantages and unavoidable disadvantages; from the illuminations on different periods in Chapter 3, we conclude that in the period of primary school, more attention is paid to the Direct Method, the Audio-Lingual Method and the Audio-Visual Method, the middle school and university place more emphases on the Communicative Approach. An overall conclusion is that multiple teaching methods and approaches should be used in English teaching.

Nowadays, there is a common trend in the foreign language pedagogy that an eclectic attitude to the various pedagogic schools the foreign language teachers and scholars take. ${ }^{[1]}$ So China's English teaching could also choose to take this kind of attitude towards different pedagogic schools, taking advantage of the merits and avoiding the demerits of them in English teaching.

Therefore, a suitable way for English teaching in China is to combine different pedagogic methods and approaches together according to different conditions and take advantage of the merits of each method, not to emphasize just one method, ignoring other methods. By doing this, the students' language competence could be truly consolidated and improved and more excellent English learners will be cultivated.

\section{Acknowledgements}

I would like to acknowledge and extend my sincere gratitude to my beloved family and my colleagues. Without their support, I could not have come so far.

\section{References}

[1] Changyong Wu,Ying Li.Jiaojifadeshilun[J].Foreign Languages and Their Teaching,1998,(11).

[2] Dingfang Su.FLT in China:Problems and Suggested Solutions [M]Shanghai, Shanghai Foreign Languge Education Press, 2004

[3] Hawatt, A. P. R. A History of English Language Teaching. Oxford: Oxford University Press, 1984.

[4] Mueller, T. "An Audio-Visual Approach to Modern Language Teaching." The Modern Language Journal 39 (1955).

[5] Richards, Jack C. and Richard Schmidt. Longman Dictionary of Language Teaching and Applied Linguistics. Beijing: Foreign Language Teaching and Research Press, 2005.

[6] Xu Hui. A Study on the Implementation of Formative Assessment in College English Teaching [D]. Zhejiang: Zhejiang University, 2006.

[7] Xu Yan. Implementing Classroom-based Assessment to Improve Foreign Language Learning in China Colleges [D]. Zhejiang: Zhejiang University, 2005.

[8] Zhang Yurang. The Puzzles and Worries: an Empirical Research on Current Situations of English Teaching in High Schools [D]. Zhejiang: Foreign Language and Culture and International Communication College of Zhejiang University, 2008. 